\title{
BETA CONVERGENCE ANALYSIS OF GROSS VALUE ADDED IN THE HIGH-TECHNOLOGY MANUFACTURING INDUSTRIES
}

\author{
Andreea Claudia ȘERBAN (D 1*, Elena PELINESCU(D2), \\ Andrei Silviu DOSPINESCU(D) 3 \\ ${ }^{1}$ Department of Economics and Economic Policies, Bucharest University of Economic Studies, \\ Bucharest, Romania \\ ${ }^{2}$ Institute for Economic Forecasting, "Costin C. Kiritescu” National Institute for Economic Research, \\ Romanian Academy, Calea 13 Septembrie No. 13, District 5, 050711 Bucharest, Romania \\ ${ }^{3}$ Centre for Industry and Services Economics, "Costin C. Kiritescu" National Institute for Economic \\ Research, Romanian Academy, Calea 13 Septembrie No. 13, District 5, 050711 Bucharest, Romania
}

Received 19 February 2021; accepted 13 September 2021; first published online 06 December 2021

\begin{abstract}
The paper examines the recent developments in the high-technology manufacturing sectors in the EU28 countries, focusing on the $\beta$-convergence of gross value added in the Manufacture of computers, electronic, and optical products, and the Manufacture of basic pharmaceutical products and pharmaceutical preparations. We employ two dynamic panel models estimated using the system of generalized method of moments (GMM) to address the risk of an endogeneity bias. The panel data analysis indicates a higher convergence for the Manufacture of computer, electronic, and optical products at $16.4 \%$ compared to $2.2 \%$ for the Manufacture of basic pharmaceutical products and pharmaceutical preparations, which is consistent with the existence of fewer barriers and higher exposure to competition in the case of the first analyzed sector. In the context of the role of the high-technology manufacturing industries as an engine of growth and the existing performance differences between the EU28 countries in terms of gross value added in the analyzed sectors, we investigated the $\beta$-convergence for two groupings EU15 and the new $\mathrm{EU}$ member states. We found that the new EU member states display a higher $\beta$-convergence rate than EU15, but also that they have a lower capital intensity. The result highlights the potential risk of some of the new EU member states becoming laggers in terms of the underlying factors behind gross value added as investment and labour force.
\end{abstract}

Keywords: high-tech manufacturing, gross value added per firm, investment, labour force, capital intensity, convergence, dynamic panel models.

JEL Classification: L69, O47, O33.

^Corresponding author. E-mails: andre_serban@yahoo.com; andreea.serban@economie.ase.ro 


\section{Introduction}

The world is facing a new challenge at the beginning of the fourth industrial revolution. After the steam engine, electricity, the emergence of computers, and digital technology, the ongoing industrial revolution is characterized by the fusion of advances in many technologies, e.g., robotics, artificial intelligence, Internet of Things, quantum computing, 3D printing, nanotechnology, biotechnology, etc. The complexity of the production processes has increased as the world moves toward a new industrial revolution. The new revolution will occur at an exponential rate as a result of the deeply interconnected world we live in and the fact that these technologies will amplify each other as they develop and will create transformative changes in many economic sectors (Schwab, 2016; World Economic Forum [WEF], 2016; Park, 2018). These changes will reshape the consumption and production pattern and will imply radical changes in all industries, disruptive technologies being considered the enabler of a more abundant world (Maresch \& Gartner, 2020).

Both the development and diffusion of innovation are faster in the fourth industrial revolution. However, beyond its speed, returns to scale are also important, and they are the result of the automation processes. It refers to fully integrating information and computer technology (ICT) and automation technology into production and, consequently, to the integration in the value-added chain with the aid of digitalization. This enables real-time readjustments owing to highly flexible processes. Notably, in manufacturing, networking and increased transparency facilitate working in embedded systems and shifting from centralized to local production (KPMG, 2016).

Historically, the manufacturing industry has played a key role in ensuring sustainable economic growth. Recent technological changes have led to profound adjustments of the production processes at the economic sector level with a negative effect on employment, especially for the low-skilled labour force. In addition, the integration of the manufacturing industry into the global value chain has become a challenge for economies that are not globally competitive. In the case of the manufacturing industry, compared to other sectors, capital, skills, and technological complexity of produced goods play a key role in the decision to relocate productive capacity. As a consequence, the economies in which the manufacturing industry can thrive are characterized by a highly skilled labour force and an investment environment, including here competitive venture capital. These characteristics suggest that the manufacturing industry is at a critical point, especially in economies that need to become more competitive.

Economic growth and employment characteristics are impacted by the structure and dynamics of production. Under the current challenges of climate change, the production processes are also adjusting. The efforts are focused mainly in countries with high innovation potential, but all countries make efforts to be more innovative to become more competitive in global markets.

This paper aims to investigate the recent developments in the high technology manufacturing sectors in the European Union countries. Globalization, increased competition, and the rapid growth of developing countries raise the question of the role of the high technology sectors as an engine of economic growth and their role in the catching-up process. In this vain, the economic convergence of the new EU member states increasingly depends on their 
performance in the high-technology manufacturing sectors, which is becoming a critical driving force of growth. Against this background, this paper investigated the beta convergence of gross value added in the high-technology manufacturing industries in the EU28 countries as well as for the EU15 and the new EU member states groupings. We used the aggregation of high-technology manufacturing, based on NACE Rev.2 at 2-digits level ${ }^{1}$ and analyzed the $\beta$ convergence of gross value added in the Manufacture of computer, electronic, and optical products, and the Manufacture of basic pharmaceutical products and pharmaceutical preparations. To this end, we use two dynamic panel models based on the system of generalized method of moments (GMM) to tackle the endogeneity bias issue.

The rest of the paper is structured as follows: the next section comprises the literature review on high-tech manufacturing and its implications, Section 2 provides an overview of the high-tech manufacturing industry in the EU, Section 3 describes the methodology, data used and investigates the results. The last section provides the conclusion.

\section{High-tech manufacturing - theoretical framework}

\subsection{Technological changes - implication to manufacturing industry}

In the context of the manufacturing industry's fundamental role as a driving force of economic growth, it is important to investigate the impact of recent technological changes on this industry and its component activities. The new technologies reduce the labour force directly involved in the production processes, also generating a reduction of the total costs. This is a challenge for economies that traditionally have relied on labour costs to ensure competitiveness and force these economies to adopt new technologies to remain competitive. In some industries (e.g., automotive industry) a major part of the work is done by robots. In other industries, the work volume is too low, or the production patterns change too rapidly in response to new demands or innovation (e.g. small-scale manufacturing or relatively advanced industries) to make the automation process worthwhile (Knight, 2012).

The role of manufacturing as an economic sector continues to evolve, both in developing and developed countries. For developing countries, it ensures higher productivity and increasing living standards for the labour force transitioning out of agriculture. For developed countries, it acts as a driving force for productivity, innovation, export, and competitiveness. As economies develop, manufacturing also becomes important in reducing resource consumption and energy use, therefore, addressing environmental concerns. The sector is and will be energized by information technology, new production processes, innovations in production, and materials that will lead to the development of new products but also to improving, reinventing, or changing the existing ones (Manyika et al., 2012). Technologies have a major impact on production systems through the increased level of automation, which benefits both the producers (speed, quality, diversification, precision, small lot size, the cost, and productivity etc.) and employees (increasing safety in the usage of the technologies, user-friendly interfaces, etc.).

\footnotetext{
${ }^{1}$ High-technology manufacturing based on NACE Rev. 2 at 2-digits level is comprised of only the two sectors analyzed in this paper.
} 
The manufacturing sector success depends on a range of factors such as access to the highly skilled labour force and access to the low-cost labour force, access to an efficient transportation and logistics infrastructure, proximity to demand, availability and low prices of resources and energy, and the possibility to access innovation (Manyika et al., 2012).

The manufacturing industry is an engine of economic development, stimulating the competitiveness of the economy. From a historical perspective, there is a significant correlation between the dynamics of the manufacturing industry and the growth of GDP. Kaldor (Kaldor, 1966) investigated the existence of a positive relationship between the increase in production of the manufacturing industry and the GDP growth. Recent studies show that countries with the highest GDP per capita growth are countries that have also recorded significant increases in value added and employment in the manufacturing industry (Hallward-Driemeier \& Gaurav, 2017; Szirmai \& Verspagen, 2015; Fagerberg \& Verspagen, 1999). Other studies (Fagerberg et al., 2009; Cappelen et al., 2000) examined the impact of new technologies on productivity, employment, and gross value added in specific sectors of the manufacturing industry.

The new technologies, especially automation, have a negative impact on employment, mainly on the medium and low skills labour force (Acemoglu \& Autor, 2011; Mokyr et al., 2015). In terms of value added, the effect of introducing new technologies is positive, especially for companies that are integrated into the global value chain (Low \& Pasadilla, 2016; Hallward-Driemeier \& Nayyar, 2017).

The emergence of high technologies has accelerated the sustainable transformation of manufacturing industry and moved traditional manufacturing away from labour intensive, low-skill jobs and low added value towards high-skill jobs, high value-added and high-quality production (Bell, 1973; Zheng et al., 2020). This relocation currently entails moving from low-tech to high-tech, calling for an increased importance of research and development and a higher share of associated expenditure in total expenditures (Kelley et al., 2004). This conclusion contradicts the assumption that low or inadequate productivity is responsible for the low manufacturing competitiveness (Krugman \& Lawrence, 1994). The IMF found that the decline in manufacturing employment characterises the successful economic development and is associated with increased living standards. They conclude, based on a sample consisting of the US and other developed countries, that deindustrialization is associated with high productivity growth in manufacturing (Rowthorn \& Ramaswamy, 1997).

In manufacturing, the core jobs follow well-defined repetitive operations and, as a result, can easily be performed by computers/robots and be codified using computer software (Acemoglu \& Autor, 2011). Even under these circumstances, the gains from using technologies are distributed in a manner that gradually benefits a growing share of the labour force (Frey \& Osborne, 2017). Referring to the convergence of the robot density in manufacturing industries in EU, Jungmittag (2021) showed that country specific factors did not influence the speed of catching-up process and convergence of densities of industrial robots in manufacturing industries. The author also suggests that the intensified deployment of robots does not slow down the convergence of labour market productivities in EU.

Increasing productivity due to innovation and new technologies led to an employment decrease in manufacturing and rising output. Especially in developed economies, the employ- 
ment in manufacturing as a share of total employment will decrease due to productivity gains and increased competition, which determine the specialization in highly skilled activities. In addition, as the service sector is growing, the share of manufacturing in total employment decreases.

As long as the industry is more competitive, the production costs and output prices fall. A sign of high-tech industry maturing is the decline of employment and value added per employee. High-tech manufacturing value added is evidence of an industry in ascension. Its decline suggests that products become routine or lower margin. As a result, as economic conditions change rapidly, high-tech manufacturing's current performance does not guarantee the same future success. There are factors enabling continuous performance increases in high-tech manufacturing as a source of advancement and powerful technologies (Kelley et al., 2004):

- R\&D - is essential for developing cutting-edge innovation and for emerging technologies and for strengthening the role of disruptive technologies in manufacturing and other economic sectors;

- adequate education for the development and use of new technologies. The highly skilled labour force is more flexible in adapting to the rapidly changing environment;

- digitalisation, automation, and technology impact all production processes in the high-tech manufacturing sector and foster the deployment of production in an integrated, flexible, intelligent, and efficient manner (KPMG, 2016);

Under these circumstances, the new production technologies will favourably impact the firm performance and productivity and will increase the value added (Gillani et al., 2020). These new technologies will also be adapted to the environmental needs of current and future societies. Both producers and governments have to adapt to the new technologies. For producers, this implies rethinking and retooling their internal activities and for governments reassessing their competitive advantages and development strategies. To position their economies on a path of sustainable growth, governments should be able to i) set policies to encourage and help the development and diffusing of new technologies, ii) deliver the needed education and lifelong learning programs for the labour force and iii) develop the infrastructure (WEF, 2017). New technologies also contribute to sustainability, directly or indirectly, and studies showed that developed countries successfully achieved sustainability in manufacturing sectors, while the rate of sustainability adoption in developing countries is significantly poorer (Yadav et al., 2020).

\subsection{Importance of the convergence process in EU - Towards smart manufacturing}

The fourth industrial revolution will enable smart factories, smart and connected machines, and systems. Industry 4.0, Smart Manufacturing, Smart Factory are concept resulted from the propagation in global manufacturing of the fourth industrial revolution.

Smart Manufacturing is a concept introduced in the United States to highlight the role of information in addressing the increased variability of the industry. It becomes the focus of global manufacturing, transformation, and upgrading (Qi \& Tao, 2018). In this vain, smart manufacturing technologies aim at delivering the right information at the right time and 
reduce the risk of technology adoption and development. It is considered the core of the modern production and manufacturing industry as it is moving towards digitalization (Lee et al., 2020), bringing speed and flexibility (Cioffi et al., 2020). The final objectives of Smart Manufacturing are high quality and efficiency, energy savings, environmental sustainability, economic, and social development (Lu et al., 2016). Production flows needs to become increasingly flexible, intelligent, and reconfigurable. The intelligent manufacturing industry requires certain basic technologies that will allow the equipment and machines to adapt their behaviour in response to different situations and needs, taking into account previous experience and the capacity to acquire new knowledge.

The focus of a successful high-tech manufacturing sector should be to maintain the speed of transformation and this requires a good and fast adaptation of technologies within the business process to create value. The deployment of new high technologies, their high initial costs, and new services associated, etc. lead to a new trend in business management reflecting rapid changes and the need of adjustment to the new changing business environment. This creates a network where the technologies are increasing separated from production activities (Piech \& Radosevic, 2006; Zheng et al., 2019), Manufacturing as a Service becoming a very popular business model which provides better and most cost-effective solutions. These types of services are more likely to develop in high-tech manufacturing, considering their impact on innovation, research, and development. Manufacturing as a Service includes benefits like faster and less expensive new technologies, a better-balanced workload for producers, and supports producers who cannot yet bid on individual projects. These potential benefits open a wide range of business models for manufacturers like design, equipment, management, maintenance, simulation, etc., all provided as a service (Microsoft Dynamics, 2019). At the EU level, the manufacturing industry aims to contribute to social and environmental sustainability, impacting growth and jobs. For addressing these challenges, increased cooperation between government and industry is needed. Technological innovation steaming from hightech manufacturing plays a key role in transforming new products into competitive, accessible, and affordable new products. Without these features or as a result of the late entrance to the market, these new products cannot generate value added for society. The channels for creating value within a society can be different: endowment with natural resources, increased food production, and service delivery. For the EU, the manufacturing industry is essential for generating value as it has already almost maximised its food production and the potential of increasing employment and productivity in the services sector is also limited. The EU is the leading global manufacturing sector not in terms of market share, but in terms of the factories of the future (European Commission, 2013).

The role of technology in supporting the transition of manufacturing to greater resource efficiency and the need to ensure that ICTs and innovative ideas are used for new products to create jobs and growth were already stressed at EU level (European Commission, 2010). The EU manufacturing needs to increase its capacity for creative destruction and reallocation of resources, which implies investment and reallocation within manufacturing to sectors, activities with higher value added (Veugelers, 2017). High-tech manufacturing implies structural changes in the economy, impacting producers, consumers, and society as a whole (Figure 1). 


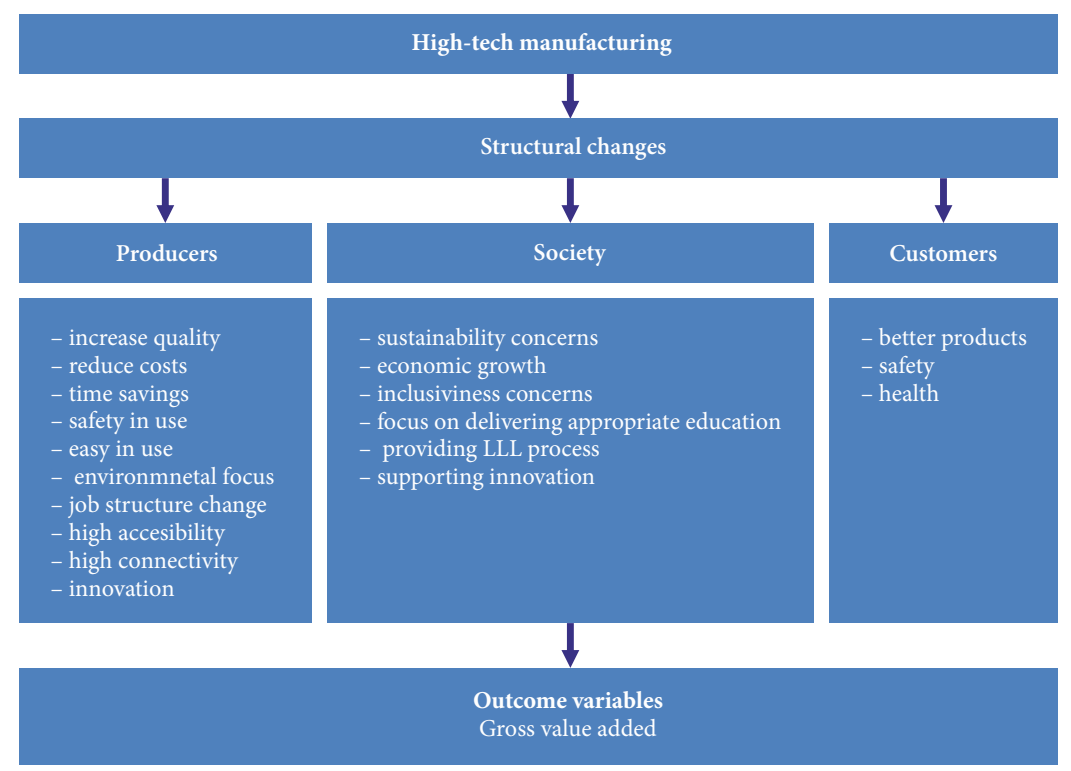

Figure 1. Analyzed transmission channels

The rapid economic growth of developing countries raises questions on the sustainability of economic convergence. The economic growth potential depends both on the creation of new economic sectors as well as on the internal transformation of those that already exist (Smith, 2002). Under these circumstances, technological advances are of major importance in driving economic growth in the EU. The technological adaptation and technological changes become a dominant feature of the convergence process within the EU (Chen \& Dahlman, 2004; Assuncao et al., 2015). Rodrick (Rodrik, 2011a, 2011b) found that technologies spread more rapidly between industrial sectors than across economies and, as a result, industrial sectors are more likely to converge compared to countries. Lack of digital strategy and resource scarcity emerged as barriers to the implementation of high technologies both in developed and developing countries, while improvement of government regulations (in developing countries) and technological infrastructure (in developed countries) are needed to promote the adoption of these technologies (Raj et al., 2020).

A recent study examines the convergence of countries in terms of productivity, highlighting that the better initial level of education, higher institutional quality, political stability, greater complexity of economies, policies that encourage participation in global value chains have influenced, since 2000, the transition of countries to the group of high level convergence countries, contributing to the reduction of the existing gaps (Kindberg-Hanlon \& Okou, 2020). Also, the impact of local specific factors and macroeconomic characteristics were found as positively influencing the recovery after recession for high convergence club countries from EU (Mazzola \& Pizzuto, 2020). Other studies analyzed the positive impact of innovation and international trade for the convergence process in developing countries from Central and Easter Europe (Grela et al., 2017). 
To ensure economic growth and development, new technologies should be used in conjunction with measures to enable economies to take advantage of new production opportunities and to reduce the development gaps within the EU. The next step should be to shift from using new technologies to the development and deployment of new technologies (Magacho \& McCombie, 2018). In this respect, the necessary ingredients are (Dahlman \& Andersson, 2000; Freeman, 2002):

- an economic and institutional framework providing incentives for the deployment and use of new technologies;

- a skilled labour force is able to develop, use, and improve new technologies;

- an efficient communication and transportation infrastructure;

- an innovative society both at the public and private level adapting new technologies to changing needs.

The gap between developed and developing countries can be reduced by a mix of organisational factors. The availability of new technologies at the EU level may not imply the immediate shift to high-tech manufacturing or high-tech services if the national economies do not have the appropriate competencies, skills, institutions, and other supporting conditions (e.g. transportation and communication infrastructure) (Eliasson et al., 2004). Productivity improvements as a result of new technologies are accompanied by labour market changes (skills and organisation of work) (Organisation for Economic Cooperation and Development [OECD], 2001). The high-tech manufacturing industry can promote economic growth as a result of increased productivity and structural changes. Consequently, new technologies act as enablers of growth and catching-up process in developing economies (Battisti et al., 2018).

\section{The high-tech manufacturing industry in the European Union - an overview}

At the EU level, the activities of the manufacturing industry are grouped into three categories according to their technological intensity, considering also the high technology and biotechnological patents (Eurostat, 2018): High-technology, Medium-technology (including Medium-high-technology and Medium-low-technology) and Low-technology (Eurostat, 2021). The high-technology activities were grouped on the basis of the Standard International Trade Classification (SITC). The patents were grouped on the basis of the International Patent Classification (IPC). High-tech industries are defined by Eurostat according to their technological intensity and aggregated based on NACE Rev. 2. At 2-digit level, the high-tech manufacturing industries are Manufacture of basic pharmaceutical products and pharmaceutical preparations (C21) and Manufacture of computer, electronic, and optical products (C26).

Statistical data are publicly available at the manufacturing industry's aggregate level of activity and are not available for each technology. This did not allow the analysis of the disaggregated impact at the technology level, but only the analysis of the impact at the aggregate level of the technological groups according to their characteristics.

The evolution of the manufacturing industry activities grouped by technological intensity reflects the impact of technology on employment and gross added value (GVA). Because some countries do not have data on gross value added for 2019 (9 from 28), we will focus our analysis on 2018, for which only 3 countries, Luxembourg, Ireland, and Malta do not have 
publicly available data. The high-technology manufacturing activities are predominantly located in the developed countries of Western and Central Europe: Denmark (34.3\%), Belgium (17.2\%), Hungary (15.4\%), Cyprus (14.9\%), Finland (14.6\%) and Slovenia (14.5\%) (Figure 2). Romania has the lowest share of high-technology activities, respectively, 3.3\% compared to the EU average of $11.7 \%$ in 2018 . Moreover, the structure of the manufacturing industry in Romania is atypical: the share of medium-technology manufacturing is $41.8 \%$, above the EU28 average: $27.3 \%$.

The results are in accordance with the relative specialization index, which indicates that Romania's manufacturing industry is the least specialized in terms of high-tech industries among the analysed countries (Figure 3 ). The relative specialization index ${ }^{2}$ is calculated based on the standard Balassa (1965) index to assess the technological content of manufacturing industries. It is determined by reporting the share of manufacturing sector by technological intensity GVA (High Technology, Medium Technology or Low Technology) in the total manufacturing GVA to the share of the same manufacturing industry in the total manufacturing industry. Western and Central European countries are, on average, the best performers. Romania also experienced a decrease in the degree of specialization in high-tech industries during the transition period and subsequently during the European Union's pre-accession period. After the EU accession, the integration in the European value chain and in the European single market played a positive role for the Romanian manufacturing industry.

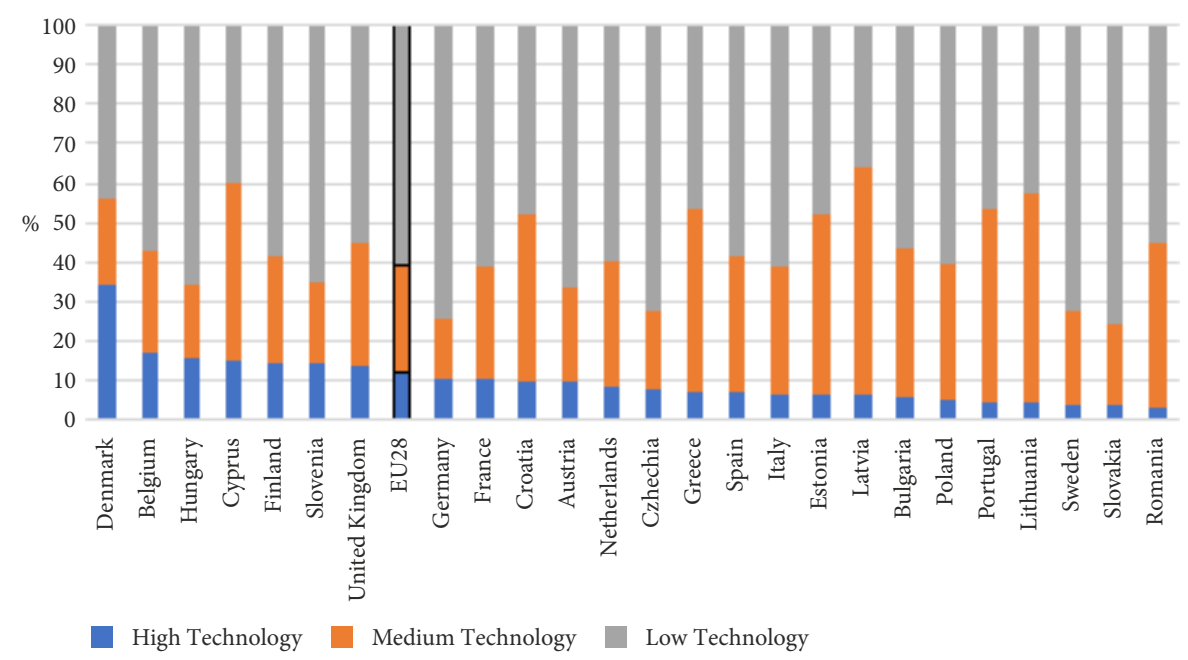

Figure 2. The manufacturing industry structure based on GVA by technological intensity, 2018 (source: author computation based on Eurostat, 2021)

\footnotetext{
2 Industrial relative specialisation index $=\frac{G V A_{i j} / G V A_{M j}}{G V A_{i} / G V A_{M}}$, where: $G V A_{i j}$ is Gross value added of country $j$ of manufacturing sector $i$ (High Technology, Medium Technology or Low Technology); $G V A_{M j}$ is GVA of country j of Manufacturing industry as a whole; $G V A_{i}$ is $G V A$ of manufacturing sector i in EU; GVA $M$ is GVA of manufacturing industry in EU.
} 


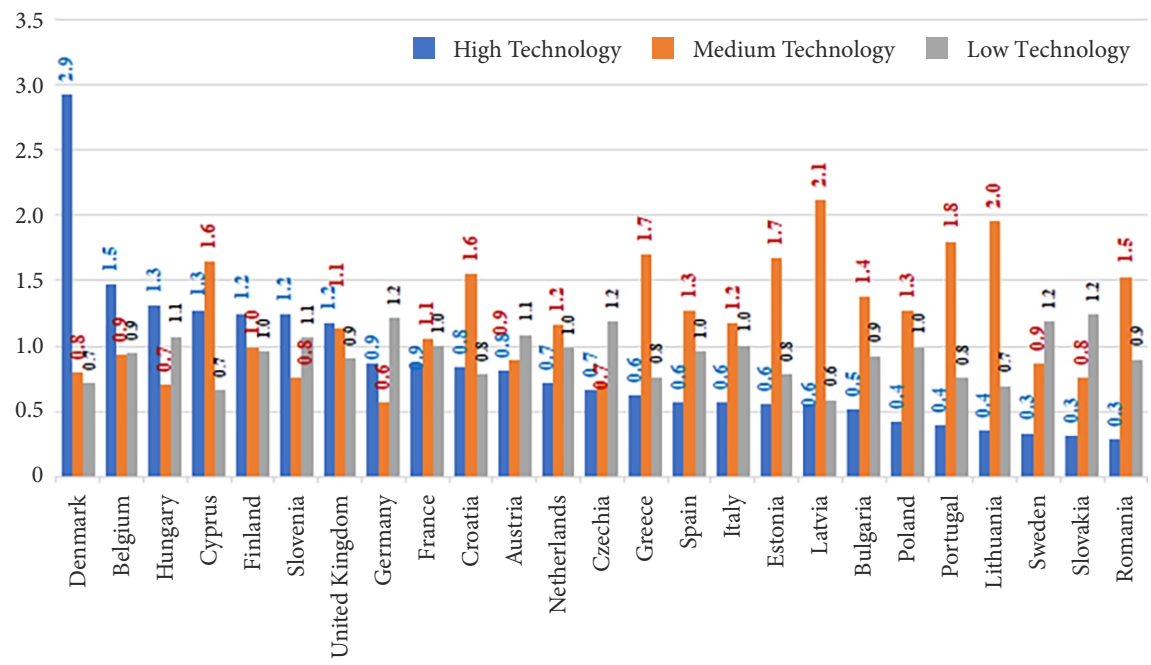

Figure 3. Industrial relative specialization index, 2018

(source: author computation based on Eurostat, 2021)

For a better understanding of the high-tech manufacturing industry performance, we will review the most important indicators characterizing the industry. Companies' turnover, according to Eurostat, in the high-tech manufacturing industry in Belgium, Germany, Italy, France, and United Kingdom represented $75.78 \%$ of the total high-tech manufacturing turnover of EU countries included in the analysis in 2017 and $83.13 \%$ in 2018 . The gross value added of the high-tech manufacturing industry in Belgium, Germany, Italy, France and United Kingdom represented $80.89 \%$ of the total value added in the EU high-tech manufacturing in 2017 and $81.59 \%$ in 2018. If we analyse the turnover per enterprise, the highest value is recorded in France EUR 58.1 million in 2017 and EUR 60.3 million in 2018 followed by Belgium with EUR 49.4 million in 2017 and EUR 58.9 million in 2018, and Germany EUR 22.12 million in 2017 and EUR 24.28\% million in 2018. Romania is below the median, with EUR 3.4 million in 2017 and EUR 4.1 million in 2018.

In terms of gross added value per enterprise, the highest values were recorded in Denmark (EUR 18.3 million in 2017 and 19.0 million in 2018) followed by Belgium (EUR 15.6 million in 2017 and EUR 18.95 million in 2018), and Finland (EUR 10.2 million in 2017 and 8.5 million in 2018).

While the value added and personnel costs increased, the absolute number of jobs in the EU manufacturing has declined mostly as a result of offshoring to Asia, which has slowed lately (Barbieri et al., 2018). The employment in high-tech manufacturing as percentage of total employment in the manufacturing industry is very low in Eastern and Baltic countries (e.g., Portugal 3.4\%, Lithuania 2.1\%, Latvia 4.4\%, Romania 4.4\%) in 2020. The employment in high-tech manufacturing for all EU New Member States is below the average of EU countries included in the analysis (6.7\% of employment in the manufacturing industry), excepting Hungary, Slovenia, Malta and Cyprus (Figure 4). 


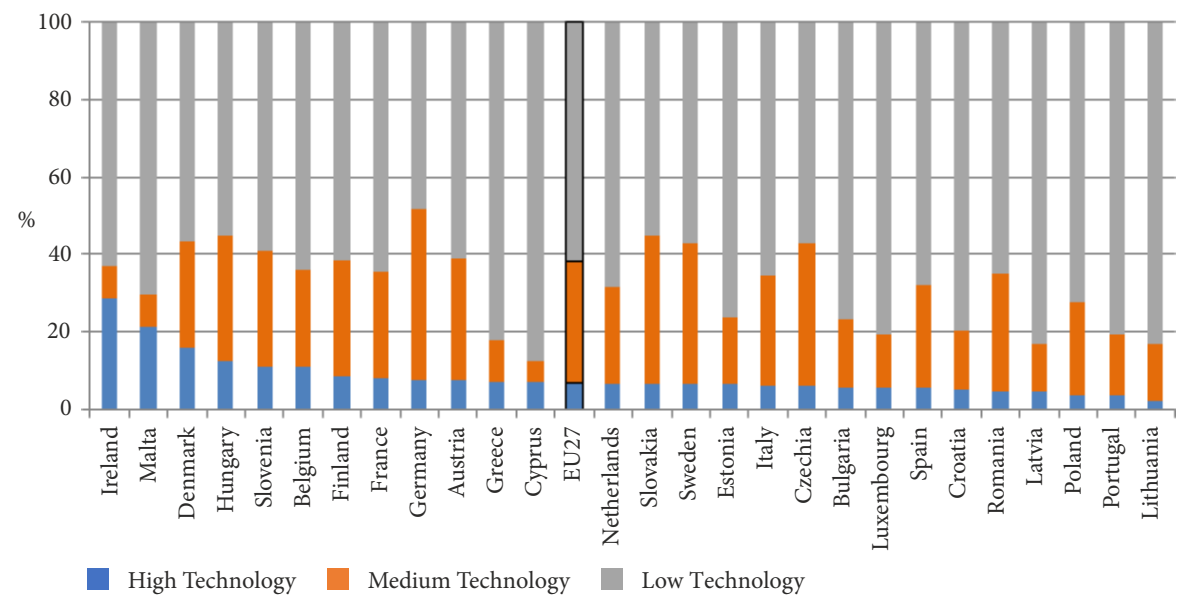

Figure 4. Share of employment based on technology sectors in total employment in manufacturing in EU in 2020 (source: author computation based on Eurostat, 2021)

As manufacturing is shifting to high-tech production, the job profile will shift towards higher value-added jobs, determining a structural change in the labour market. The educational system needs to ensure a better correlation of supply and demand on the labour market taking into account the increased demand for a highly skilled labour force (engineers, technical workers, etc.) in high-tech manufacturing. Considering the challenge of ageing in the EU, the education policies should provide an efficient lifelong learning process, increasing the number of retraining programs and vocational training. The change in the labour market composition, namely, the increasing share of highly skilled workers in total employment, highlights the role of skills and their positive impact on the value added in the manufacturing industry.

The high-tech manufacturing sector employs new innovative technologies to meet the demand for new products and improve the manufacturing processes' efficiency. The job structure in manufacturing has changed due to automation, robotics, better transportation, information technology, etc. In the EU, 25.2\% of employed in manufacturing have tertiary education, while in high-tech manufacturing, the share of tertiary educated personnel is higher at $46.4 \%$ (Figure 5). A larger percentage of tertiary education in high-tech manufacturing compared to manufacturing is recorded in all EU countries. These characteristics highlight the importance of adaptability and skills in high-tech manufacturing.

The strategic role of research and development (R\&D) in the manufacturing industry has increased, reflecting new technological opportunities and competitive pressures. The Council of the European Union stated that the EU economy should be focused on enhancing human capital, research and development, innovation, and digital transformation to tackle the sustainability and competitiveness challenges efficiently (European Council, 2017). Increasing share of the high-tech manufacturing in the economy depends on reinforcing public research and building research and development $(\mathrm{R} \& \mathrm{D})$ infrastructure at the enterprise level. Northern EU countries are the best performers in terms of enterprise R\&D expenditure in high-tech manufacturing (Figure 6). 


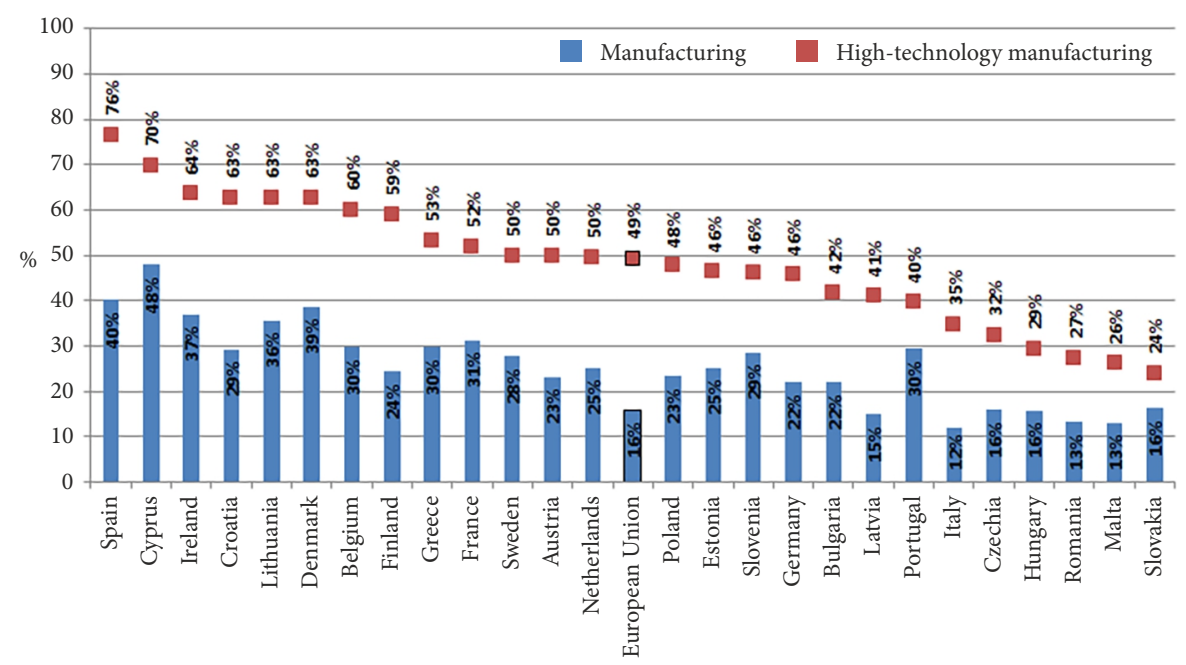

Figure 5. Share of tertiary education (levels 5-8) in total employment in manufacturing and high-tech manufacturing, 2020 (source: author computation based on Eurostat, 2021)

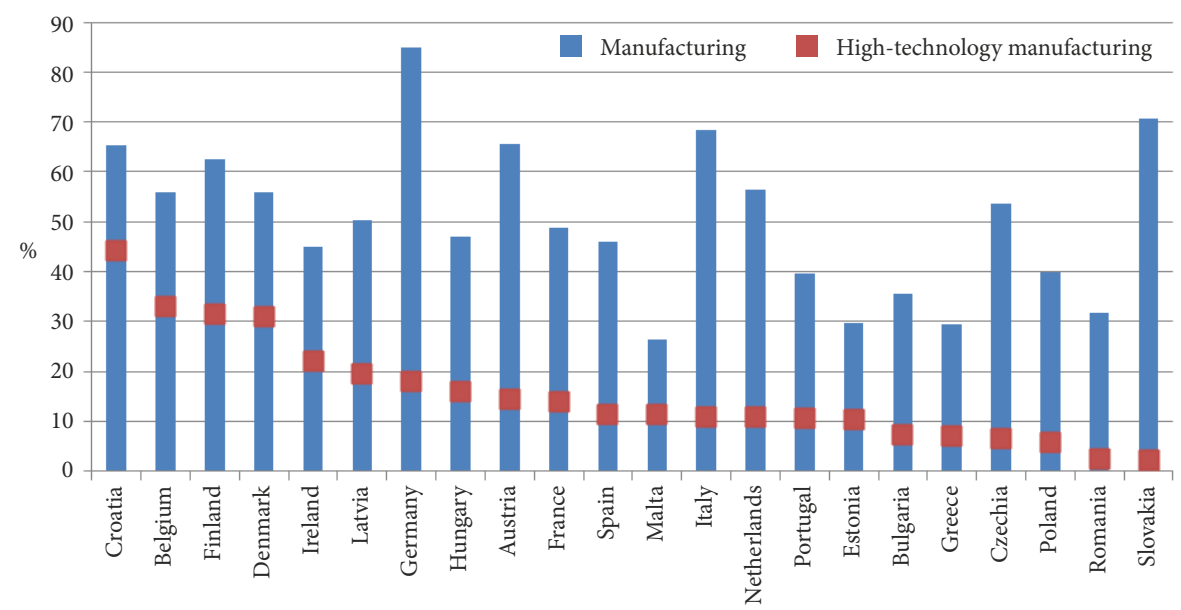

Figure 6. Business enterprise $\mathrm{R} \& \mathrm{D}$ expenditure in manufacturing and in high-tech manufacturing (as \% of total R\&D expenditure), 2017 (source: author computation based on Eurostat, 2021)

Manufacture of basic pharmaceutical products and pharmaceutical preparations (C21) encompasses a chain of public and private organisations that discover, develop, and manufacture medicines. More than any other industry, this manufacturing sector is highly dependent on research and development (Mikulic, 2021). The high technologies accelerate the discovery, and development of new products with high therapeutic effects and reduced associated risks. The companies in pharmaceutical industries operate in multinational markets and their activities are subject to various regulations and policies (Spilker, 1994; International Labour Organization [ILO], 2012). The value added in this sector represents $5.58 \%$ of the total manufacturing sector value added (Figure 7). Belgium and Denmark record the highest levels at 


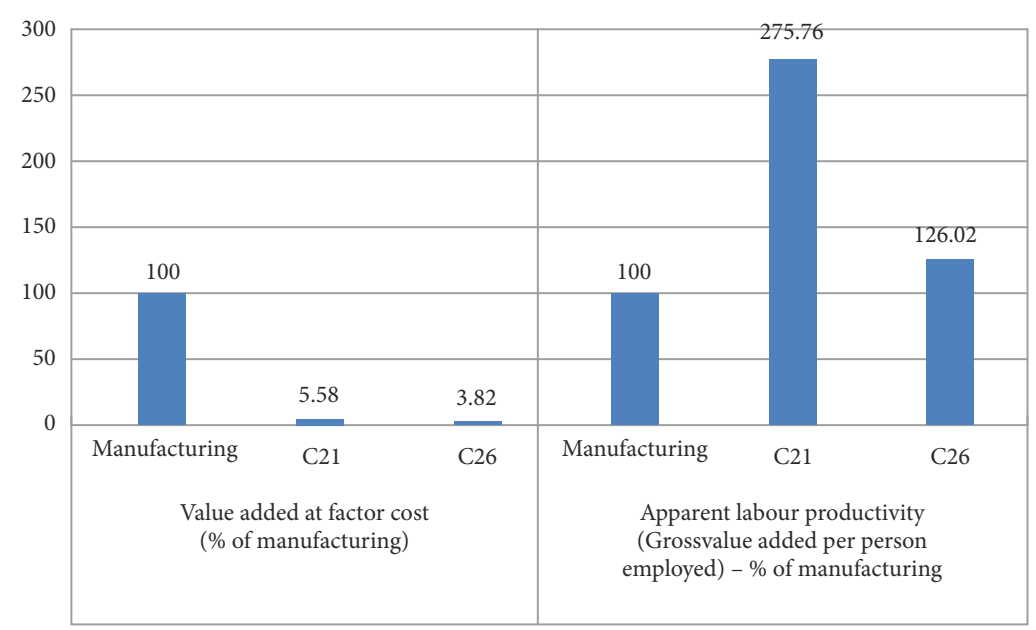

Note: Only countries that have data reported for 2018 were considered in computation for C26 (without Ireland, Cyprus, Latvia, Luxembourg, Malta).

Figure 7. High-tech manufacturing performance, 2018

(source: author computation based on Eurostat, 2021)

17.75\% and 20.4\%, respectively. Some of the New Member States record the lowest values: Estonia $0.33 \%$, Slovakia $0.47 \%$, Czech Republic 1.08\%, Poland 1.42\%, and Romania $1.94 \%$. The apparent labour productivity (calculated as GVA per person employed) in this sector at the EU level represents $183.7 \%$ of the EU manufacturing sector average. The best performers are also the Northern countries, which record levels above EU average (Finland 328\%, Belgium $314 \%$, or Denmark $258.9 \%$ compared to the manufacturing sector).

The manufacture of computer, electronic and optical products (C26) covers four main subsectors, i.e., electronic components and boards; computers and peripheral equipment; communication equipment; consumer electronics. The sector is characterized by strong global competition and a short product life cycle, which emphasizes the role of $\mathrm{R} \& \mathrm{D}$. The sector is also continuously changing not only as a result of international competition but also as a result of the increasing diversification of customer preferences and increasing miniaturization of components. The skills mix depends on the R\&D intensity and the degree of competitiveness of the sector: new member states have more assemblers, mechanics, or machinery workers, while the EU-15 has a more skilled labour force like engineers, professionals etc. (European Commission, 2001, 2009). Aggregated data at the EU level for 2018 indicate that the sector gross value added at EUR 89.16 billion represented 3.82\% of GVA in manufacturing (Figure 7), Hungary, and the Netherland record the highest levels: $9.5 \%$ and $6.25 \%$ in total manufacturing, followed by Estonia 5.67\%, Denmark 5.57\%, Finland 5.44\%, Germany $5.43 \%$, France $5.15 \%$. The lowest values are recorded by Greece 1.13\%, Spain $1.31 \%$, Portugal $1.88 \%$, Sweden $2.11 \%$, Poland $2.31 \%$, Italy $2.57 \%$, and Romania $2.92 \%$. At the EU level, the apparent labour productivity (calculated as GVA per person employed) in this sector represents $126.02 \%$ of the manufacturing sector's labour productivity. The best performing EU countries are Netherland 176.2\%, Denmark 125.6\%, Belgium 121.9\%, Austria 112.5\%, France $96.5 \%$, Germany $90.6 \%$. 


\section{Methodology, results, and discussion}

\subsection{Data and methods}

The paper investigates the $\beta$-convergence (beta convergence) of gross value added in hightechnology manufacturing industries, focusing on the Manufacture of computer, electronic, and optical products and the Manufacture of basic pharmaceutical products and pharmaceutical preparations. The explanatory variables considered in the analysis were: (i) gross value added (GVA) per firms; (ii) gross fixed capital formation; (iii) the investment rate as a proxi for capital (Baldacci et al., 2004; Levine \& Renelt, 1992; Qu et al., 2017) and a key determining variable in the accumulation of the physical capital stock (Kaldor, 1957); (iv) the labour force, expressed in terms of total hours worked (Table 1). This was preferred over the number of persons employed to account for the different working time regimes (Hsieh \& Klenov, 2010; Aghion \& Howitt, 2007). The data was taken from Eurostat and covered the period 2005 to 2018 .

The analysis of the beta convergence of gross value added in the high-technology manufacturing industries was based on two dynamic panel models estimated using the GMM method to address the possible presence of an endogeneity bias. Both fixed-effects IV and OLS estimators are vulnerable to biases (Roodman, 2006), prompting the use of lagged values of the endogenous variable as instruments. The approach allows tackling the endogeneity and measurement errors in the case of lagged endogenous variables as well as in the case of other explanatory variables.

To check the consistency of the estimators obtained using GMM, we considered two specification tests, namely, Arellano and Bond serial correlation test, which tests for first- and second-order autocorrelation in the first-differenced errors and the Sargan test of overidentifying restrictions, which examines the overall validity of the instruments by comparing the moment conditions to their sample analogue.

The paper used the standard $\beta$-convergence approach. As in Sala-i-Martin (1996) we assumed coefficient a to be constant across economies and $\beta$-convergence to hold for all the economies in the panel.

$$
\ln \left(y_{i, t}\right)=a+(1-\beta) \ln \left(y_{i, t-1}\right)+u_{i, t},
$$

where $0<\beta<1$, and the errors $\mathrm{u}$ have mean zero and finite variance.

Table 1. Model variables (source: authors' elaboration)

\begin{tabular}{|l|l|l|}
\hline \multicolumn{1}{|c|}{ Variable used in the models } & \multicolumn{1}{c|}{ Computation } & \multicolumn{1}{c|}{ Source of data } \\
\hline Gross value added per firm & $\begin{array}{l}\text { Chain linked volumes (2005), } \\
\text { million euro/ enterprises }\end{array}$ & Author own calculation \\
\hline Gross value added (GVA) & $\begin{array}{l}\text { Chain linked volumes (2005), } \\
\text { million euro }\end{array}$ & Eurostat data [nama_10_a64] \\
\hline Enterprises (firms) & Number & Eurostat data [sbs_na_sca_r2] \\
\hline $\begin{array}{l}\text { Gross fixed capital formation } \\
\text { (GFCF) }\end{array}$ & $\begin{array}{l}\text { Chain linked volumes (2005), } \\
\text { million euro }\end{array}$ & Eurostat data [nama_10_a64] \\
\hline Investment rate & Percent of GFCF in GVA & Author own calculation \\
\hline Total employment domestic concept & Thousand hours worked & Eurostat data [nama_10_a64_e] \\
\hline
\end{tabular}


The functional form used in the paper was obtained by algebraic manipulation of Eq. (1) that gives us the equation:

$$
\ln \left(\frac{y_{i, t}}{y_{i, t-1}}\right)=a-\beta \ln \left(y_{i, t-1}\right)+u_{i, t} .
$$

A vector of explanatory variables was added to Eq. (2), reflecting the production inputs, capital and labour. The explained variable in Eq. (2) was the growth of gross value added per firm (constant price, reference year 2005). The paper tested various functional representations with capital and labour as explanatory variables. Based on the soundness of the statistical results and the economic consistency of the coefficients, the ratio between the capital input expressed as the investment rate and the labour input expressed as thousand hours worked was used. The ratio is a proxy for capital intensity, which is especially relevant given that the analysis focuses on high-technology manufacturing industries. All indicators were taken from the Eurostat database.

\subsection{Results and discussions}

We have employed two dynamic models using the GMM method to analyze the beta convergence of gross value added in the high-technology manufacturing industries. The results of the first model (Table 2 ) indicate that the $\beta$-convergence rate estimate is significant. Gross value added is converging in both analysed high-technology manufacturing industries. The convergence is higher at $16.4 \%$ in the case of the Manufacture of computer, electronic, and optical products compared to $2.2 \%$ in the case of Manufacture of basic pharmaceutical products and pharmaceutical preparations. This is consistent with the existence of fewer barriers and higher exposure to competition in the case of the first analysed sector. The higher exposure to competition is also reflected in the difference between the results of the first analyzed sector and the overall real GDP convergence rate of around 2 percent found in the literature (Barro et al., 1991; Mankiw et al., 1992; Armstrong \& Read, 2002; Rivas \& Villarroya, 2016). The sign of the capital intensity coefficient, namely, IR_L, indicates the positive impact of investment on the sectorial gross value added. The longer time frame needed to pass from the product concept to the market in the case of the pharmaceutical sector is reflected in the lag of the capital intensity variable.

The convergence club hypothesis was also tested to account for the possible heterogeneity between European Union countries. We split the countries into two clusters. The first cluster consists of the EU15 countries, which are more developed and innovative, and the second cluster represents the countries that joined the European Union after 2004. The decision to split the countries into the above-mentioned clusters was also based on the extensive use of the EU15 cluster by the Eurostat, the World Bank, OECD, and other institutions to report various statistical data. To further substantiate the grouping of the countries, we compared the kernel density estimates of the gross value added per firm for the two groups. The EU15 countries' distribution displays higher average values compared to the new EU member states' distribution for both analysed high-technology manufacturing industries (see Figure 8). We have used the Kolmogorov-Smirnov test to investigate the statistical significance of the difference between the distributions. The null hypothesis of the equality of the distribution 
Table 2. Testing the beta convergence of gross value added in the high-technology manufacturing industries, based on a dynamic panel model ${ }^{1}$ (source: authors calculation using STATA 15)

\begin{tabular}{|l|c|c|}
\hline \multicolumn{3}{|c|}{ Dependent variable: $\ln$ (gGVAperfirm) } \\
\hline & $\mathrm{S} 1$ & $\mathrm{~S} 2$ \\
\hline \multirow{2}{*}{$\ln ($ GVA per firmt-1) } & $-0.164^{* * *}$ & $-0.022^{\star}$ \\
\cline { 2 - 3 } & $(-5.46)$ & $(-1.66)$ \\
\hline \multirow{2}{*}{$\ln \left(\mathrm{IR} \_L t-2\right)$} & $0.137^{* * * *}$ & \\
\hline \multirow{2}{*}{$\ln ($ IR_Lt-4) } & $(2.99)$ & $0.034^{* * *}$ \\
\hline \multirow{2}{*}{ constant } & & $(2.28)$ \\
\hline AB(1) & & 0.079 \\
\hline AB(2) & 0.232 & $(0.34)$ \\
\hline P-value for Sargan test & $0.79)$ & 0.07 \\
\hline
\end{tabular}

Legend: gGVAperfirma - represents the growth of the ratio of value added at factor cost and the number of enterprises; IR - represents the ratio between the capital input expressed as the investment rate and the labour input expressed as thousand hours worked; S1 - Manufacture of computer, electronic and optical products; S2 - Manufacture of basic pharmaceutical products and pharmaceutical preparations.

Note: ${ }^{1}$ Based on a dynamic panel data model using system GMM estimators. Number of observations 236

$2 *, * *, * * *, * * * *$ denote significance at $10 \%, 5 \%, 3 \%$ and $1 \%$ level, $t$ statistics in parenthesis;

${ }^{3} \mathrm{AB}(1)$ and $\mathrm{AB}(2)$ is the p-value of the Arellano and Bond test for first and second order autocorrelation, respectively;

${ }^{4}$ The overidentification of the model was tested using the Sargent test.

functions was rejected at the 3\% level in the case of Manufacture of computer, electronic, and optical products and at $1 \%$ level in the case of Manufacture of basic pharmaceutical products and pharmaceutical preparations. The p-value for the Kolmogorov-Smirnov test was 0.015, and the D-Statistics was 0.445 in the case of Manufacture of computer, electronic, and optical products and 0.0 and 0.75 respectively for the Manufacture of basic pharmaceutical products and pharmaceutical preparations.

We have tested various functional forms for the two high-technology manufacturing industries, for the EU15 and the new EU member states groupings. The statistical tests applied in Table 2 were also applied in this case. The results were significant only for the Manufacture of computer, electronic, and optical products.

The results (see Table 3 ) indicate that the $\beta$-convergence rate is higher for the new EU member states at $27.8 \%$ compared to $21.9 \%$ in the case of the EU15 countries. The higher convergence rate in the case of the two analyzed groups compared to the EU28 aggregate, reflects existing heterogeneity between countries at the EU28 level (see also Figure 8). The impact of the capital intensity variable, namely, IR, is positive and higher in the case of the EU15 countries. Several key variables are critical for the success of the high-technology sectors, like the presence of a skilled and educated workforce, a healthy financing environment, 
Table 3. Testing the beta convergence of gross value added in the case of Manufacture of computer, electronic, and optical products for EU15 and the new EU member states ${ }^{1}$ (source: Authors calculation using STATA 15)

\begin{tabular}{|l|c|c|}
\hline \multicolumn{3}{|c|}{ Dependent variable: $\ln$ (gGVA per firm) } \\
\hline \multirow{2}{*}{$\ln ($ GVA per firmt-1) } & EU15 member states & New EU member states \\
\hline \multirow{2}{*}{$\ln ($ IR_Lt-2) } & $-0.219^{* * *}$ & $-0.278^{* * * *}$ \\
\cline { 2 - 3 } & $(-2.95)$ & $(-3.79)$ \\
\hline \multirow{2}{*}{ constant } & $0.292^{\star * * *}$ & $0.152^{\star * * *}$ \\
\cline { 2 - 3 } & $(4.51)$ & $(3.62)$ \\
\hline $\mathrm{AB}(1)$ & 0.11 & $-0.138^{\star}$ \\
\hline $\mathrm{AB}(2)$ & $(1.25)$ & $(-1.97)$ \\
\hline P-value for Sargan test & 0.03 & 0.09 \\
\hline
\end{tabular}

Legend: gGVAperfirma - represents the growth of the ratio of value added at factor cost and the number of enterprises; IR - represents the ratio between the capital input expressed as the investment rate and the labour input expressed as thousand hours worked.

Note: ${ }^{1}$ Based on a dynamic panel data model using system GMM estimators. Number of observations 141 for the EU1515 member states and 90 for the New EU member states;

$2 *,{ }^{* *},{ }^{* *},{ }^{* * *}$ denote significance at $10 \%, 5 \%, 3 \%$ and $1 \%$ level, $t$ statistics in parenthesis;

${ }^{3} \mathrm{AB}(1)$ and $\mathrm{AB}(2)$ is the $\mathrm{p}$-value of the Arellano and Bond test for first and second order autocorrelation, respectively;

${ }^{4}$ The overidentification of the model was tested using the Sargent test.

and nonrestrictive regulations. These factors are captured in the technological readiness of a country as reflected by the Technological readiness indicator developed by The Economist Intelligence Unit [EIU] (EIU, 2018, 2020) and the Technological readiness pillar of the Global Competitiveness Index developed by the World Economic Forum (WEF, 2017, 2019). The rankings of the countries based on their technological readiness (EIU, 2018, 2020; WEF, 2019) are consistent with our results. At least ten countries out of the EU15 countries are in the top 20 in both rankings, while for the new EU member states, Estonia and Czech Republic are the highest-ranked between the 20th and 30th position. The rankings indicate that the EU15 countries have a more homogenous and higher performing technological environment than the new EU member states, explaining the higher impact of capital intensity indicated by our analysis. This higher impact highlights the gap between the two clusters of countries in respect to their capacity to innovate and captures the impact of various factors such as the massive brain migration from new member states (Docquier \& Rapoport, 2012); the impact of education on technology spillover (Benhabib \& Spiegel, 2005; Foster \& Rosenzweig, 2010; Nelson \& Phelps, 1965) and the impact of the deficient quality of management.

The positive sign of the capital intensity variable for the new EU member states can be seen as a strategic resource that can be used by the new member states to accelerate their development. However, this strategic resource should be backed up by improvements in underlying causal factors such as the quality of the workforce and the regulatory environment. 
a)

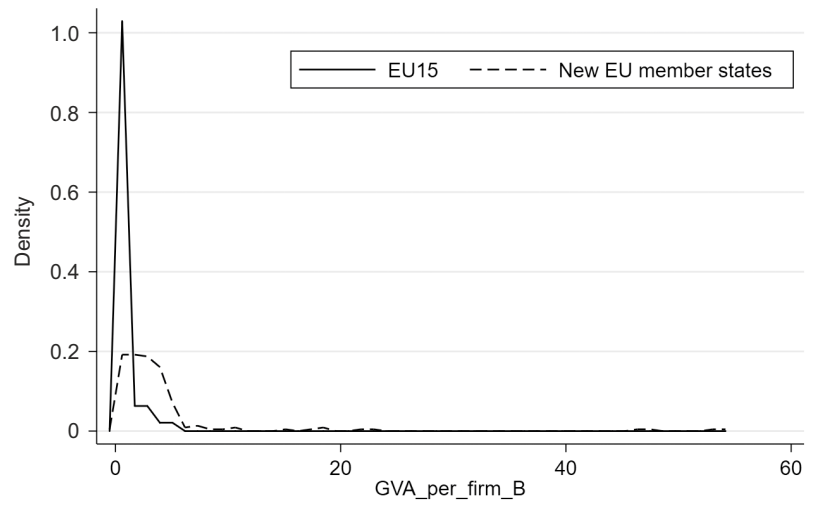

b)

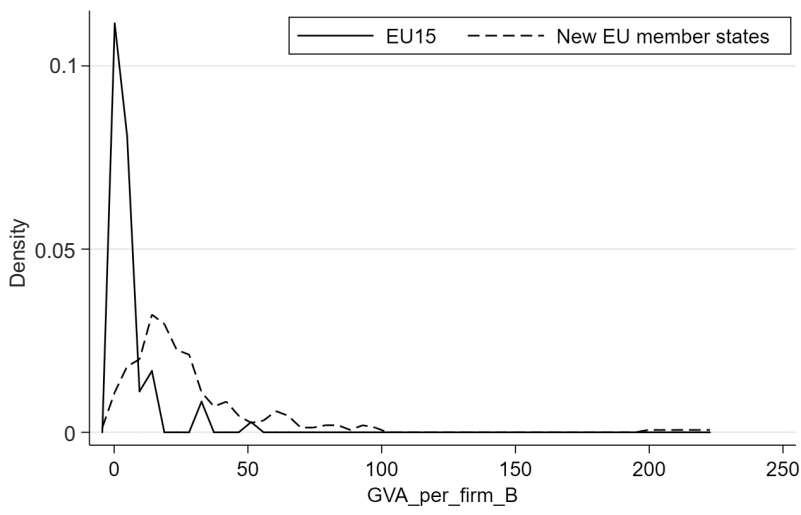

Figure 8. Comparative analysis of kernel density estimate distributions for countries in EU15 and new EU member states in Manufacture of computer, electronic, and optical products (a) and Manufacture of basic pharmaceutical products and pharmaceutical preparations (b)

(source: computation based on Stata 15)

\section{Conclusions}

The results of the analysis indicated that the $\beta$-convergence is higher for the Manufacture of computer, electronic, and optical products compared to the Manufacture of basic pharmaceutical products and pharmaceutical preparations, which is consistent with the existence of fewer barriers and higher exposure to competition in the case of the first analysed sector.

Our analysis showed that the high-technology manufacturing activities are predominantly located in the more developed countries, mainly the EU15 member states. Given the high technology sector's role as an engine of growth and the existing performance differences between EU28 countries, we investigated the $\beta$-convergence for the EU15 and the new EU member states groupings. The results indicated that the new EU member states display a higher $\beta$-convergence rate than EU15, but also that they have a lower capital intensity. This highlights the potential risk of some of the new EU member states becoming laggers in term of the underlying factors behind gross value added as investment and labour force. 


\section{Author contribution}

All authors contributed equally to this paper.

\section{Acknowledgements}

For the author Andreea Claudia ȘERBAN the work is the result of the research within the Institutional Project 932/16.06.2021: "Economic and social security in Euro-Atlantic space: actors, tools, trends", Funder: Bucharest University of Economic Studies, Romania.

\section{References}

Acemoglu, D., \& Autor, D. (2011). Skills, tasks, and technologies: Implications for employment and earnings. In O. Ashenfelter \& D. Card (Eds.), Handbook of labor economics (Vol. 4B, pp. 1043-1171). Elsevier. https://doi.org/10.1016/S0169-7218(11)02410-5

Aghion, P., \& Howitt, P. (2007). Capital, innovation and growth accounting. Oxford Review of Economic Policy, 23(1), 79-93. https://doi.org/10.1093/oxrep/grm007

Armstrong, H. W., \& Read, R. (2002). The phantom of liberty?: economic growth and the vulnerability of small states. Journal of International Development, 14(4), 435-458. https://doi.org/10.1002/jid.886

Assuncao, J., Burity, P., \& Medeiros, M. C. (2015). Is the convergence of the manufacturing sector unconditional? EconomiA, 16(3), 273-294. https://doi.org/10.1016/j.econ.2015.09.005

Balassa, B. (1965). Tariff reductions and trade in manufactures among the industrial countries. American Economic Review, 56(3), 466-473.

Baldacci, E., Clements, B., Gupta, S., \& Cui, Q. (2004). Social spending, human capital, and growth in developing countries: Implications for achieving the MDGs (IMF Working Paper WP/04/217). https://www.imf.org/external/pubs/ft/wp/2004/wp04217.pdf

Barbieri, P., Ciabuschi, F., Fratocchi, L., \& Vignoli, M. (2018). What do we know about manufacturing reshoring? Journal of Global Operations and Strategic Sourcing, 11(1), 79-122. https://doi.org/10.1108/JGOSS-02-2017-0004

Barro, R. J., Sala-I-Martin, X., Blanchard, O. J., \& Hall, R. R. (1991). Convergence across states and regions. Bookings Papers on Economic Activity, 1991(1), 107-182. https://doi.org/10.2307/2534639

Battisti, M., Del Gatto, M., \& Parmeter, C. F. (2018). Labor productivity growth: Disentangling technology and capital accumulation. Journal of Economic Growth, 23(1), 111-143. https://doi.org/10.1007/s10887-017-9143-1

Bell, D. (1973). The coming of post-industrial society: A venture in social forecasting. Basic Books.

Benhabib, J., \& Spiegel, M. M. (2005). Human capital and technology diffusion. In P. Aghion \& S. N. Durlauf (Eds.), Handbook of economic growth (Vol. 1, pp. 935-966). Elsevier. https://doi.org/10.1016/S1574-0684(05)01013-0

Cappelen, A., Eika, A. T., \& Holm, I. (2000). Resource booms: Curse or blessing? [Conference presentation]. Annual Meeting of American Economic Association 2000, Statistics Norway, Oslo.

Cioffi, R., Travaglioni, M., Piscitelli, G., Petrillo, A., \& Parmentola, A. (2020). Smart manufacturing systems and applied industrial technologies for a sustainable industry: A systematic literature review. Applied Sciences, 10(8), 2897. https://doi.org/10.3390/app10082897

Chen, D. C., \& Dahlman, C. (2004). Knowledge and development: A cross section approach (Policy Research Working Paper, No 3366). World Bank, Washington. https://openknowledge.worldbank. org/handle/10986/14163 
European Commission. (2001). Meeting society's needs and winning global leadership. European aeronautics: A vision for 2020. Luxembourg. https://www.acare4europe.org/sites/acare4europe.org/files/ document/Vision\%202020_0.pdf

European Commission. (2009). Computers, electronic and optical products. Comprehensive sectoral analysis of emerging competences and economic activities in the European Union. European Commission, DG EMPL.

European Commission. (2010). Communication from the Commission, Europe 2020. A strategy for smart, sustainable and inclusive growth. Brussels, 3.3.2010 COM(2010) 2020. https://ec.europa.eu/ eu2020/pdf/COMPLET\%20EN\%20BARROSO\%20\%20\%20007\%20-\%20Europe\%202020\%20-\%20 EN\%20version.pdf

European Commission. (2013). Factories of the future. Multi-annual roadmap for the contractual PPP under Horizon 2020. Brussels. https://www.effra.eu/sites/default/files/factories_of_the_future_2020_roadmap.pdf

Dahlman, C., \& Andersson, T. (2000). Korea and the knowledge-based economy: Making the transition. OECD, World Bank. https://openknowledge.worldbank.org/handle/10986/13845

Docquier, F., \& Rapoport, H. (2012). Globalisation, brain drain and development. Journal of Economic Literature, 50(3), 681-730. https://doi.org/10.1257/jel.50.3.681

Economist Intelligence Unit. (2018). Preparing for disruption. Technological readiness ranking. EIU. https://www.eiu.com/public/topical_report.aspx?campaignid=TechReadiness

Economist Intelligence Unit. (2020). Europe. Regional overview. (Country forecast). EIU.

Eliasson, G., Johannson, D., \& Taymaz, E. (2004). Simulating the New Economy. Structural Change and Economic Dynamics, 15(3), 289-314. https://doi.org/10.1016/j.strueco.2004.01.002

European Council. (2017). Conclusions on a future EU industrial policy strategy. http://www.consilium.europa.eu/en/press/press-releases/2017/05/29-compet-conclusions-future-industrial-policy-strategy/

Eurostat. (2018). Oficial Statisctics of European Union. https://ec.europa.eu/eurostat

Eurostat. (2021). Glossary. Oficial Statisctics of European Union. https://ec.europa.eu/eurostat/statistics-explained/index.php?title=Glossary:High-tech_classification_of_manufacturing_industries

Fagerberg, J., \& Verspagen, B. (1999). Modern capitalism' in the 1970s and 1980s. In M. Setterfield (Ed.), Growth, employment and inflation: Essays in honour of John Cornwall (pp. 113-126). Palgrave Macmillan. https://doi.org/10.1007/978-1-349-27393-5_9

Fagerberg, J., Mowery, D., \& Verspagen, B. (Eds.). (2009). Innovation, path dependency, and policy: The Norwegian case. Oxford University Press. https://doi.org/10.1093/acprof:oso/9780199551552.001.0001

Foster, A. D., \& Rosenzweig, M. R. (2010). Microeconomics of technology adoption (Center Discussion Paper No. 984). Yale University. http://www.econ.yale.edu/growth_pdf/cdp984.pdf

Freeman, C. (2002). Continental, national and sub national innovation systems - complementarity and economic growth. Research Policy, 31(2), 191-211. https://doi.org/10.1016/S0048-7333(01)00136-6

Frey, C. B., \& Osborne, M. (2017). The future of employment: How susceptible are jobs to computerisation. Technological Forecasting and Social Change, 114, 254-280.

https://doi.org/10.1016/j.techfore.2016.08.019

Gillani, F., Chatha, K. A., Jajja, M. S. S., \& Farooq, S. (2020). Implementation of digital manufacturing technologies: Antecedents and consequences. International Journal of Production Economics, 229, 107748. https://doi.org/10.1016/j.ijpe.2020.107748

Grela, M., Majchrowska, A., Michałek, T., Mućk, J., Stążka-Gawrysiak, A., Tchorek, G., \& Wagner, M. (2017). Is Central and Eastern Europe converging towards the EU15? (NBP Working Paper No. 264).

Hallward-Driemeier, M., \& Gaurav, N. (2017). Trouble in the making? The future of manufacturingled development. World Bank, Washington, DC. http://documents1.worldbank.org/curated/ en/720691510129384377/pdf/121005-PUB-ADDBOX-405304B-PUBLIC-PUBDATE-10-12-17.pdf 
Hsieh, C. T., \& Klenov, P. J. (2010). Development accounting. American Economic Journal: Macroeconomics, 2(1), 207-223. https://doi.org/10.1257/mac.2.1.207

International Labour Organization. (2012). Encyclopaedia of occupational health and safety. ILO. https://www.iloencyclopaedia.org/

Jungmittag, A. (2021). Robotisation of the manufacturing industries in the EU: Convergence or divergence? The Journal of Technology Transfer, 46, 1269-1290. https://doi.org/10.1007/s10961-020-09819-0

Kaldor, N. Causes of the Slow Rate of Economic Growth of the United Kingdom. An Inaugural Lecture. London, Cambridge University Press, 1966, 40 p., 5/- net in U.K. (1968). Recherches Economiques De Louvain / Louvain Economic Review, 34(2), 222-222.

Kaldor, N. (1957). A model of economic growth. The Economic Journal, 67(268), 591-624. https://doi.org/10.2307/2227704

Kelley, C., Wang, M., Bitko, G., Chase, M., Kofner, A., Lowell, J., Mulvenon, J., Ortiz, D., \& Pollpeter, K. (2004). High-technology manufacturing and U.S. competitiveness. RAND Corporation. https://www. rand.org/content/dam/rand/pubs/technical_reports/2004/RAND_TR136.pdf

Kindberg-Hanlon, G., \& Okou, C. (2020). Productivity convergence: Is anyone catching up? (Policy Research Working Paper No. 9378). World Bank Group. https://openknowledge.worldbank.org/bitstream/handle/10986/34425/Productivity-Convergence-Is-Anyone-Catching-Up. pdf? sequence $=4 \&$ is Allowed $=y$

Knight, W. (2012). This robot could transform manufacturing. MIT Technology Review.

KPMG. (2016). The factory of the future. Industry 4.0 - The challenges of tomorrow. Germany. https:// assets.kpmg/content/dam/kpmg/es/pdf/2017/06/the-factory-of-the-future.pdf

Krugman, P., \& Lawrence, R. Z. (1994). Trade, jobs, and wages. Scientific American, 22-27. https://doi.org/10.1038/scientificamerican0494-44

Lee, C. K. M., Huo, Y. Z., Zhang, S. Z., \& Ng, K. K. H. (2020). Design of a smart manufacturing system with the application of multi-access edge computing and blockchain technology. IEEE Access, 8, 28659-28667. https://doi.org/10.1109/ACCESS.2020.2972284

Levine, R., \& Renelt, D. (1992). A sensitivity analysis of cross-country growth regressions. The American Economic Review, 82(4), 942-963.

Low, P., \& Pasadilla, G. O. (Eds.). (2016). Services in global value chains: Manufacturing-related services. World Scientific. https://doi.org/10.1142/10073

Lu, Y., Morris, K. C., \& Frechette, S. P. (2016). Current standards landscape for smart manufacturing systems. National Institute of Standards and Technology. https://doi.org/10.6028/NIST.IR.8107

Magacho, G. R., \& McCombie, J. S. L. (2018). A sectoral explanation of per capita income convergence and divergence: Estimating Verdoorn's law for countries at different stages of development. Cambridge Journal of Economics, 42(4), 917-934. https://doi.org/10.1093/cje/bex064

Mankiw, N. G., Romer, D., \& Weil, D. N. (1992). Contribution to the empirics of economic growth. The Quarterly Journal of Economics, 107(2), 407-437. https://doi.org/10.2307/2118477

Manyika, J., Sinclair, J., Dobbs, R., Strube, G., Rassey, L., Mischke, J., Remes, J., Roxburgh, C., George, K., O'Halloran, D., \& Ramaswamy, S. (2012). Manufacturing the future: The next era of global growth and innovation. McKinsey Globa Institute. https://time.com/wp-content/uploads/2015/03/manufacturing-the-future.pdf

Maresch, D., \& Gartner, J. (2020). Make disruptive technological change happen - The case of additive manufacturing. Technological Forecasting and Social Change, 155, 119216. https://doi.org/10.1016/j.techfore.2018.02.009

Mazzola, F., \& Pizzuto, P. (2020). Great Recession and club convergence in Europe: A cross country, cross-region panel analysis (2000-2015). Growth and Change. A Journal of Urban and Regional Policy, 51(2), 676-711. https://doi.org/10.1111/grow.12369 
Microsoft Dynamics 365. (2019). 2019 Manufacturing trends report. https://info.microsoft.com/rs/157GQE-382/images/EN-US-CNTNT-Report-2019-Manufacturing-Trends.pdf

Mikulic, M. (2021). Global pharmaceutical industry - Statistics \& facts. Statista. https://www.statista. com/topics/1764/global-pharmaceutical-industry/

Mokyr, J., Vickers, C., \& Ziebarth, N. L. (2015). The history of technological anxiety and the future of economic growth: Is this time different? Journal of Economic Perspectives, 29(3), 31-50. https://doi.org/10.1257/jep.29.3.31

Nelson, R. R., \& Phelps, E. S. (1965). Investment in humans, technological diffusion and economic growth (Crowles Fundation Discussion Papers No. 189). American Economic Review, 56(2), 67-75. http://cowles.yale.edu/sites/default/files/files/pub/d01/d0189.pdf

Organisation for Economic Cooperation and Development. (2001). The new economy: Beyond the hype. The OECD Growth Project. https://doi.org/10.1787/9789264033856-en

Park, S. C. (2018). The Fourth Industrial Revolution and implications for innovative cluster policies. AI \& Society, 33(3), 433-445. https://doi.org/10.1007/s00146-017-0777-5

Piech, K., \& Radosevic, S. (Eds.). (2006). Knowledge based economy in central and eastern Europe: Countries and industries in a process of change. Palgrave Macmillan.

Qi, G. L., \& Tao, F. (2018). Digital twin, big data towards smart manufacturing and industry 4.0: 360 degree comparison. IEEE Access, 6, 3585-3593. https://doi.org/10.1109/ACCESS.2018.2793265

Qu, J., Simes, R., \& O’Mahony, J. (2017). How do digital technologies drive economic growth? Economic Record, 93(S1), 57-69. https://doi.org/10.1111/1475-4932.12340

Raj, A., Dwivedi, G., Sharma, A., Jabbour, A. B. L. D., \& Rajak, S. (2020). Barriers to the adoption of industry 4.0 technologies in the manufacturing sector: An inter-country comparative perspective. International Journal of Production Economics, 224, 107546. https://doi.org/10.1016/j.ijpe.2019.107546

Rivas, M. D. G., \& Villarroya, I. S. (2016). Testing the convergence hypothesis for OECD countries: A reappraisal (Economics Discussion Papers No 2016-45). Kiel Institute for the World Economy. http://www.economics-ejournal.org/economics/discussionpapers/2016-45

Rodrik, D. (2011a). The future of economic convergence (NBER Working Paper No. 17400). https://www.nber.org/system/files/working_papers/w17400/w17400.pdf

Rodrik, D. (2011b). Unconditional convergence (NBER Working Paper No. 17546). https://doi.org/10.3386/w17546

Roodman, D. (2006). How to do Xtabond2: An introduction to difference and system GMM in Stata (Center for Global development Working Paper 103). https://doi.org/10.2139/ssrn.982943

Rowthorn, R., \&, Ramaswamy, R. (1997). Deindustrialization: Causes and implications (International Monetary Fund Working Paper, WP/97/42). https://www.imf.org/external/pubs/ft/wp/wp9742.pdf

Sala-i-Martin, X. X. (1996). Regional cohesion: Evidence and theories of regional growth and convergence. European Economic Review, 40(6), 1325-1352. https://doi.org/10.1016/0014-2921(95)00029-1

Schwab, K. (2016). The fourth industrial revolution. World Economic Forum, Geneva.

Smith, K. (2002). What is "Knowledge Economy"? Knowledge intensive industries and distributed knowledge bases (UN/INTECH Discussion Papers).

Spilker, B. (1994). Multinational pharmaceutical companies: Principles and practices (2 ${ }^{\text {nd }}$ ed.). Raven Press.

Szirmai, A., \& Verspagen, B. (2015). Manufacturing and economic growth in developing countries, 1950-2005. Structural Change and Economic Dynamics, 34, 46-59.

https://doi.org/10.1016/j.strueco.2015.06.002

Veugelers, R. (2017). Remaking Europe: The new manufacturing as an engine for growth. Bruegel, Brussels. https://www.bruegel.org/wp-content/uploads/2017/09/Remaking_Europe_blueprint.pdf 
World Economic Forum. (2016). The future of jobs: Employment, skills and the workforce strategy for the fourth industrial revolution. Geneva. http://www3.weforum.org/docs/WEF_Future_of_Jobs.pdf

World Economic Forum. (2017). The global competitiveness report 2017-2018. Geneva. http:// www3.weforum.org/docs/GCR2017-2018/05FullReport/TheGlobalCompetitivenessReport2017 \%E2\%80\%932018.pdf

World Economic Forum. (2019). The global competitiveness report. Geneva. http://www3.weforum.org/ docs/WEF_TheGlobalCompetitivenessReport2019.pdf

Yadav, G., Kumar, A., Luthra, S., Garza-Reyes, J. A., Kumar, V., \& Batista, L. (2020). A framework to achieve sustainability in manufacturing organisations of developing economies using industry 4.0 technologies' enablers. Computers in Industry, 122, 103280.

https://doi.org/10.1016/j.compind.2020.103280

Zheng, J., Chen, A., Zheng, W., Zhou, X., Bai, B., Wu, J., Ling, W., Ma, H., \& Wang, W. (2020). Effectiveness analysis of resources consumption, environmental impact and production efficiency in traditional manufacturing using new technologies: Case from sand casting. Energy Conversion and Management, 209, 112671. https://doi.org/10.1016/j.enconman.2020.112671

Zheng, P., Zang, Z. X., Chen, C. H., \& Khoo, L. P. (2019). A survey of smart product-service systems: Key aspects, challenges and future perspectives. Advanced Engineering Informatics, 42, 100973. https://doi.org/10.1016/j.aei.2019.100973 